\title{
Studi Eksperimental Perubahan Amplitudo Gelombang Pada Aliran Minyak - Air Rezim Stratified Wavy Dalam Pipa Horizontal
}

\author{
A. I. Santosa* dan A. Widyaparaga \\ Departemen Teknik Mesin dan Industri, Fakultas Teknik, Universitas Gadjah Mada. \\ Jl. Grafika No. 2, Kompleks UGM, Yogyakarta 55281, Indonesia \\ *e-mail: ari.santosa03@gmail.com
}

\begin{abstract}
Abstrak
Penelitian mengenai amplitudo gelombang pada aliran dua fasa minyak-air rezim pola aliran stratified wavy telah dilakukan dalam beberapa penelitian sebelumnya. Namun mengingat banyaknya variasi properties fluida kerja, variasi dimensi dan geometri saluran, serta variasi kondisi parameter operasi maka menurut penulis, penelitian yang sudah ada saat ini masih belum mencukupi untuk memahami bagaimana pengaruh perubahan kecepatan superfacialdan jarak dari inlet sumber aliran terhadap amplitudo gelombang. Penelitian dilakukan untuk menginvestigasi perubahan amplitudo terhadap kenaikan kecepatan superfacial dan terhadap jarak inlet pada aliran dua fasa minyak air dalam rezim pola aliran stratified wavy dalam kondisi sebelum dan saat transisi ke rezim aliran non stratified flow pada fluida kerja. Fluida minyak yang digunakan adalah kerosene dengan masa jenis $781,1 \mathrm{~kg} / \mathrm{m}^{3}$, viskositas $1,3 \mathrm{mPa} \cdot \mathrm{s}$ dan interfacial tension $0,167 \mathrm{mN} / \mathrm{m}$. Kerosene dan air dialirkan pada pipa horizontal yang terbuat dari bahan akrilik dengan diameter $24 \mathrm{~mm}$. Parameter operasi kecepatan superfacial minyak dijaga konstan sebesar $0,073 \mathrm{~m} / \mathrm{s}$. Perbandingan aliran kecepatan superfacial air terhadap kecepatan superfacial minyak pada kondisi entry (input ratio) sebesar 1; 2; 3 dan 4. Proses pengambilan data dilakukan pada titik pengamatan 10D, 40D, 100D dan 220D dari inlet, dimana D adalah diameter dalam pipa. Proses perekaman dilakukan dengan high speed camera frekuensi 600 fps. Data ekseperimen diolah dengan menggunakan metode pengolahan citra untuk mendapatkan ketebalan lapisan air rata-rata dan distribusi probabilitas amplitudo pada setiap titik pengamatan. Kenaikan input ratio akan menyebabkan terjadinya kenaikan ketinggian lapisan air rata-rata sebesar $12 \%$ dengan standard deviasi 5,7 \%. Peningkatan input ratio ini juga akan meningkatkan besarnya amplitudo rata-rata pada setiap titik pengamatan dengan peningkatan tertinggi terjadi di titik $10 \mathrm{D}$ dan terendah di titik 220 D. Kenaikan input ratio menyebabkan kenaikan amplitudo antarmuka gelombang dan ketebalan lapisan permukaan air.Munculnya droplet pada gelombang merupakan tanda bahwa gelombang mengamai ketidakstabilan dan masuk ke fasa transisi (onset entrainment).
\end{abstract}

Kata kunci : Pengolahan citra, stratified wavy, stratified mixing, kecepatan superfacial, kondisi onset.

\begin{abstract}
Research on the amplitude of the two-phase oil-water flow regime stratified wavy flow pattern has been carried out in several previous studies. However, considering the many variations of working fluid properties, variations in dimensions and geometry of the channel, as well as
\end{abstract}


variations in operating parameter conditions, according to the authors of the existing research is still not sufficient to understand how the influence of changes in superfacial velocity and the effect of the distance from the flow source inlet to the wave amplitude. The study was conducted to investigate changes in amplitude due to the increment in superfacial velocity and to the inlet distance in the two-phase water oil flow in the stratified wavy flow pattern regime. Observation was divided in conditions before transition (wave growth) and during the transition to the non-stratified flow regime in the working fluid. The oil used was kerosene which has density of $781,1 \mathrm{~kg} / \mathrm{m}^{3}$, viscosity of $1,3 \mathrm{mPa} \cdot \mathrm{s}$ and interfacial tension $0,167 \times 10-3 \mathrm{~N} / \mathrm{m}$. Kerosene and water flowed in a horizontal acrylic pipe with an internal diameter of $24 \mathrm{~mm}$. The operating parameter of oil superfacial velocity were kept constant at $0,073 \mathrm{~m} / \mathrm{s}$. The ratio of the flow of superfacial velocity of water against superfacial velocity of oil at the entry point or input ratio was set to be 1;2; 3 and 4 . The data collection process was carried out using a high speed camera with observation points at 10D, 40D, 100D and 220D from the inlet, where D is the diameter in the pipe. The recording process was done with a frequency of $600 \mathrm{fps}$. The experimental data obtained were then processed using the image processing method to obtain the average water layer thickness and probability distribution of the amplitude at each observation point. An increment of the input ratio of the superfacial water velocity to oil will cause an increment in average water layer height of $12,3 \%$ with a standard deviation of 5,7\%. The increment in input ratio will also increase the magnitude of the average amplitude at each observation point with the highest increment occurs at the $10 \mathrm{D}$ and the lowest at the $220 \mathrm{D}$. At a constant oil superfacial velocity, an increment in the input ratio of the superfacial water velocity to oil will make increasing in the amplitude of the wave interface and the thickness of the surface layer of water. The increment range of amplitude at the point that is farther from the inlet will tend to decrease / smaller than the point which closer to the inlet flow. The appearance of a droplet on a wave is a sign that the wave is matching instability and is entering the phase of transition (onset entrainment condition).

Keywords : image processing, stratified wavy, stratified mixing, superfacial velocity, onset condition.

\section{PENDAHULUAN}

Studi mengenai amplitudo gelombang pada gelombang antarmuka yang terbentuk dalam aliran dua fasa minyak-air dalam rezim aliran stratified wayy merupakan hal yang sangat penting untuk memahami karakteristik fluida sebagai referensi dalam mendesain suatu sistem perpipaan. Studi tentang analisa stabilitas gelombang aliran dua fasa minyak air dalam pipa horizontal telah dilakukan secara sistematis oleh Al-Wahabai dan Angeli (2007). Gelombang antarmuka fluida minyak-air dimodelkan sebagai gelombang sinusoidal antara dua jenis fluida seperti yang ditunjukkan pada Gambar 1. Masing-masing fluida memiliki kecepatan fasa, yaitu kecepatan fasa minyak $\left(\mathrm{U}_{\mathrm{o}}\right)$ dan kecepatan fasa air $\left(\mathrm{U}_{\mathrm{w}}\right)$ yang besarnya dipengaruhi oleh kecepatan superfacial fluida dan hold up ratio aliran minyak dan air. Ketika kecepatan superfacial aliran minyak atau air meningkat, maka gelombang antarmuka juga terus mengalami pertumbuhan amplitudo hingga mencapai amplitudo dan panjang gelombang tertentu yang menyebabkan pembentukan droplet yang terpisah dari fasa continue karena turunnya amplitudo kritis gelombang. Dalam penelitian tersebut maka amplitudo gelombang menjadi salah satu parameter untuk mengetahui transisi rezim aliran. 

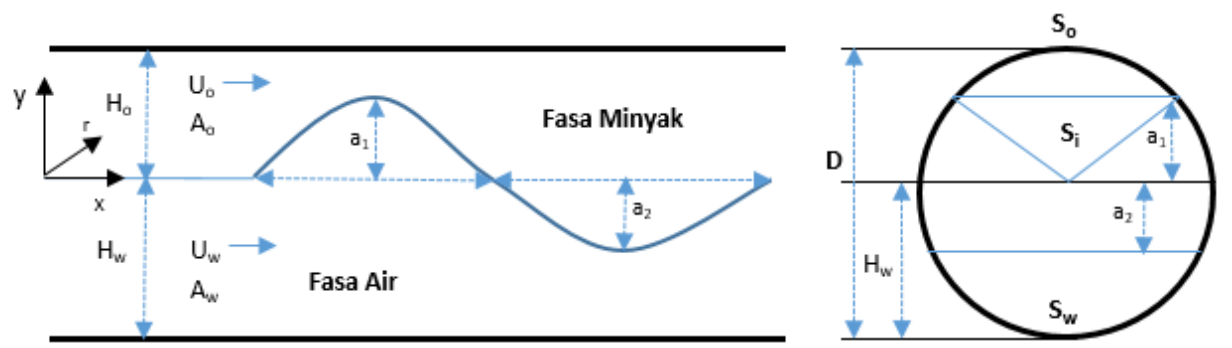

Gambar 1.Interfacial Wave Oil Water Two Phase Flow (Al-Wahabai and Angeli, 2007)

Stabilitas antarmuka gelombang pada aliran dua fasa air-minya dipengaruhi oleh gayagaya yang bekerja didalamnya. Tiga komponen gaya utama yang bekerja adalah gaya suction pressure, gaya gravitasi dan gaya interfacial tension. Amplitudo gelombang sangat berpengaruh terhadap ketiga komponen gaya tersebut. Gaya suction pressure akan membuat gelombang menjadi tidak stabil sedangkan gaya gravitasi dan gaya interfacial tension cenderung membuat gelombang menjadi stabil.

Metode pengolahan citra banyak diterapkan dalam menganalisa karakteristik gelombang yang terbentuk pada aliran 2 fasa. Marcelo S. dkk (2011) melakukan penelitian terkait amplitudo, panjang gelombang dan kecepatan gelombang pada antarmuka aliran dua fasa minyak air dengan metode pengolahan citra. Minyak yang digunakan memiliki massa jenis 828 $\mathrm{kg} / \mathrm{m}^{3}$, viskositas $300 \mathrm{mPa} \cdot \mathrm{s}$ dan interfacial tension $0,034 \mathrm{~N} / \mathrm{m}$. Fluida air dan minyak dialirkan pada pipa yang terbuat dari kaca dengan diameter dalam 0,026 $\mathrm{m}$ dengan variasi sudut kemiringan pipa dan input ratio kecepatan superfacial air terhadap minyak.

$$
\text { Froude }=\frac{U_{w}-U_{o}}{\sqrt{g \cdot \cos \theta \cdot y_{w} \cdot \frac{\pi D}{4}}}
$$

Marcelo S. dkk (2011) menggunakan perbandingan antara amplitudo terhadap panjang gelombang sebagai fungsi bilangan Froude untuk memperkirakan stabilitas gelombang. Perhitungan bilangan Froude dapat dilihat seperti pada persamaan (1), dimana $\theta$ merupakan sudut kemiringan pipa, g merupakan konstanta gravitasi dan $\mathrm{y}_{\mathrm{w}}$ merupakan fraksi volume air. Bilangan Froude menunjukan perbandingan antara gaya yang cenderung menyebabkan tidak stabil akibat kecepatan relative antara fasa air dan minyak terhadap gaya yang cenderung menyebabkan gelombang menjadi stabil karena pengaruh gravitasi. 


\section{METODE PENELITIAN}

\subsection{Peralatan Penelitian}

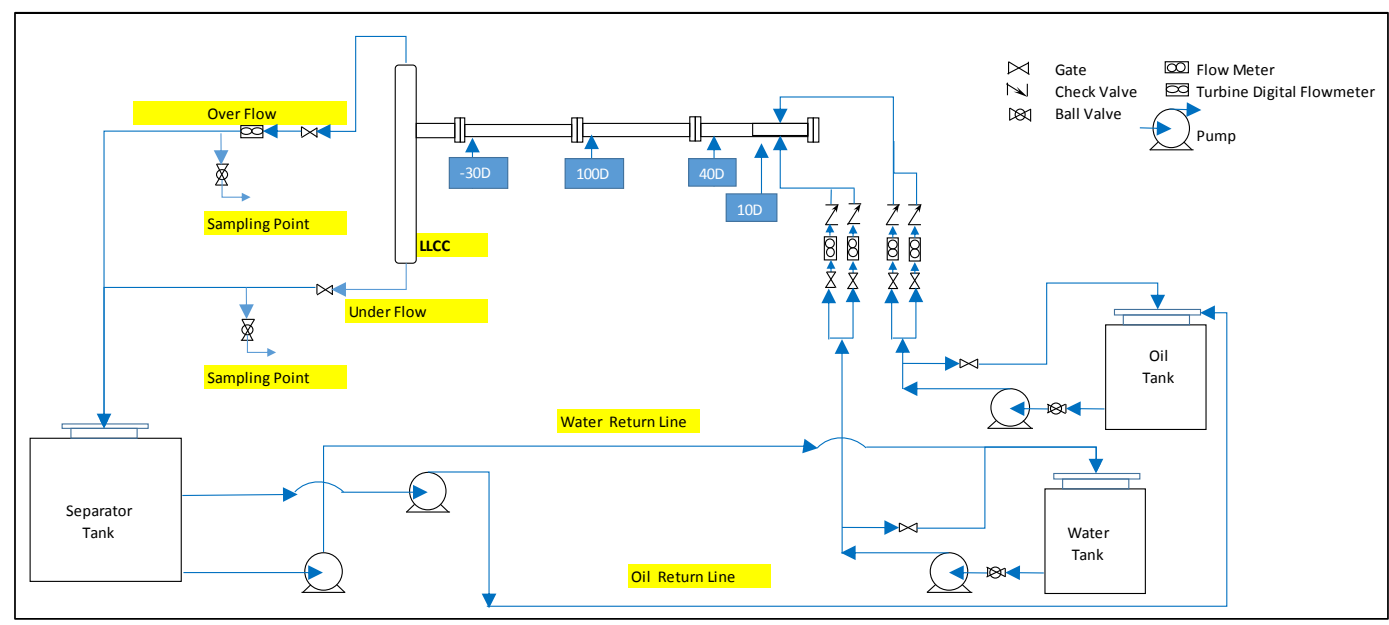

Gambar 2. Skema Peralatan Penelitian

Skema diagram peralatan penelitian ditunjukkan pada Gambar 2. Air dan kerosene dialirkan ke dalam T-junction mixer menggunakan pompa sentrifugal. Setiap saluran minyak dan air dipasang dua jenis katup. Gate valve untuk mengatur aliran fluida dan check valve untuk mencegah aliran balik fluida guna meningkatkan akurasi pembacaan meter aliran. Antara dua katup, dipasang dua flow meter untuk mengukur jumlah aliran melalui sistem. Dua rota meter dipasang di saluran air dan dua flow meter dipasang di saluran minyak. Setelah melewati T-junction mixer, fluida campuran minyak-air akan mengalir di dalam pipa akrilik dengan diameter $24 \mathrm{~mm}$ sepanjang 6 meter. Titik pengamatan pengambilan data terdiri dari 4 titik dengan jarak dari inlet aliran sejauh 10D, 40D, 100D dan 220D, dimana D merupakan diameter dalam pipa. Guna menjaga kualitas pencahayaan citra yang diambil, maka pada titik pengamatan dipasang lampu LED serta dipasang correction box untuk menghilangkan efek pembiasan cahaya sehingga batas pipa dan aliran dapat terlihat lebih jelas pada saat pengambilan data. Proses penyimpanan data menggunakan alat high speed camera Phantom Micro M310.

\subsection{Prosedur Penelitian}

Penelitian dilakukan dengan menggunakan fluida kerja minyak tanah (kerosene) dan air (water). Adapun massa jenis dan tegangan permukaan dari kedua fluida tersebut dapat dilihat pada tabel 1 berikut.

Tabel 1. Properties Fluida

\begin{tabular}{|c|c|c|}
\hline Properties & Water & kerosene \\
\hline Density & $981,7 \mathrm{~kg} / \mathrm{m}^{3}$ & $781,1 \mathrm{~kg} / \mathrm{m}^{3}$ \\
\hline IFT & \multicolumn{2}{|c|}{$0,167 \mathrm{mN} / \mathrm{m}$} \\
\hline
\end{tabular}

Investigasi karakteristik amplitudo gelombang dilakukan dengan mengatur parameter operasi kecepatan superfacial fluida kerja, yaitu kecepatan superfacial minyak dijaga konstan pada kecepatan $0,073 \mathrm{~m} / \mathrm{s}$ sedangkan kecepatan superfacial air bervariasi dengan rasio kecepatan air terhadap minyak sebesar 1, 2, 3 dan 4 . 
Tabel 2. Parameter Operasi Kecepatan Superfacial Penelitian

\begin{tabular}{|c|c|c|c|c|c|}
\hline & \multicolumn{4}{|c|}{ Input Ratio (Vsw / Vso) } \\
\hline & & 1 & 2 & 3 & 4 \\
\hline \multirow{4}{*}{ 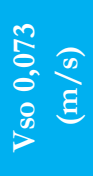 } & $10 \mathrm{D}$ & 1 & 2 & 3 & 4 \\
\hline & $40 \mathrm{D}$ & 5 & 6 & 7 & 8 \\
\hline & $100 \mathrm{D}$ & 9 & 10 & 11 & 12 \\
\hline & $220 \mathrm{D}$ & 13 & 14 & 15 & 16 \\
\hline
\end{tabular}

Parameter operasi ini dilakukan di keempat titik pengamatan, sehingga total pengambilan data yang dilakukan sejumlah 16 data seperti yang terlihat pada Tabel 2 . Pengamatan secara visual terhadap bentuk gelombang dan munculnya droplet dilakukan secara cermat guna mendukung proses analisa dan pengolahan citra.

\subsection{Proses Pengolahan Citra}

Proses penglahan citra hasil eksperimen untuk mengukur amplitudo gelombang dilakukan dengan menggunakan software MATLAB R2016a. Adapun langkah-langkah dalam melakukan pengolahan citra gelombang aliran dijelaskan sebagai berikut.

Langkah 1. Membaca citra video dengan terlebih dahulu mengubah format file video menjadi format .avi

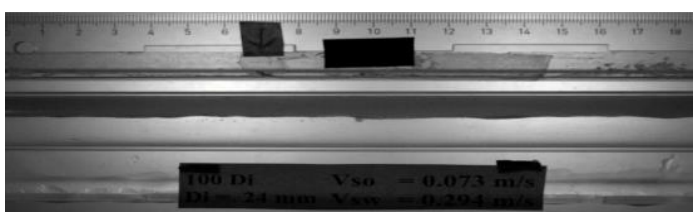

Gambar 3. Pembacaan Gambar

Langkah 2. Memotong citra guna memfokuskan obyek yang akan diteliti yaitu hanya mencakup pada bagian dalam pipa saja (image cropping).

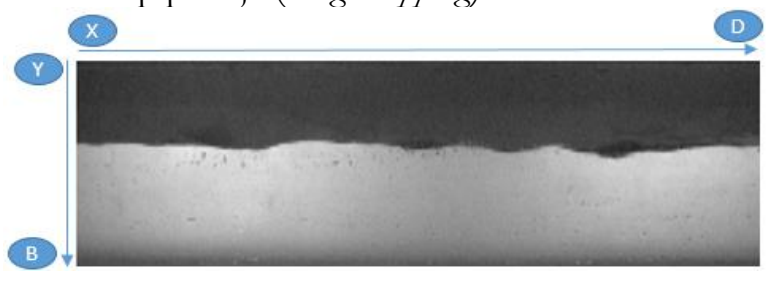

Gambar 4. Image Cropping

Langkah 3. Mengkonversi susunan warna dari format RGB (Red Green Blue) yang meiliki 255 elemen warna menjadi susunan warna binary yang hanya memiliki 2 elemen warna, yaitu 0 (hitam) or 1 (putih).

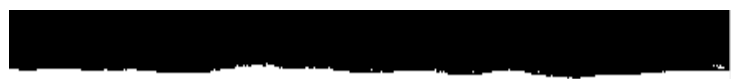

Gambar 5. Convert to Binary Image

Langkah 4. Proses filtering, yaitu proses identifikasi garis antramuka aliran, dengan melakukan pembacaan warna binary secara vertikal dari atas ke bawah pada setiap kolom matrix 
warna untuk medapatkan elemen warna dengan nilai 1. Setelah elemen warna ini diperoleh maka mengkonversi elemen warna lain sebagai elemen warna dengan nilai 0 .

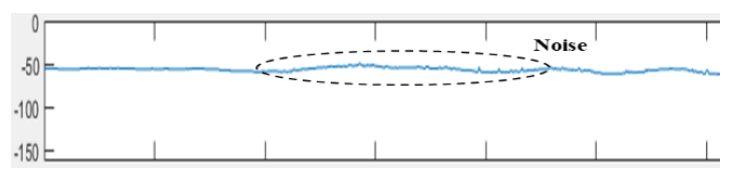

Gambar 6. Proses Filtering

Langkah 5. Denoising, meningkatkan keakurasian hasil pengolahan citra dengan meng eliminasi noise atau spike data.

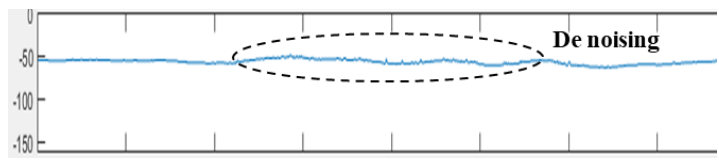

Gambar 7. Proses Denoising

Langkah 6. Melakukan pengambilan data ketinggian lapisan air dan amplitudo. Identifikasi ketinggian lapisan air dilakukan pada 5 titik pengamatan dengan jarak antar titik pengamatan sejauh D (diameter dalam pipa). Amplitudo gelombang diperloleh dengan mencari selisih puncak ketebalan air tertinggi dikurangi ketebalan rata-rata. Dan jarak antar puncak gelombang diukur sebagai panjang gelombang.

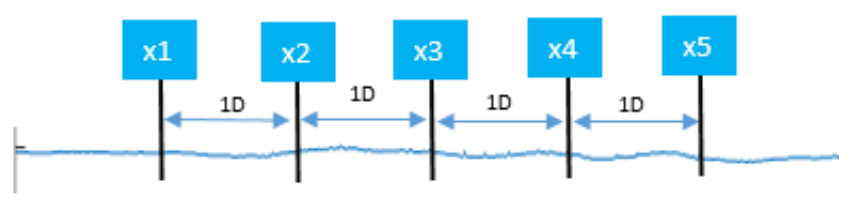

Gambar 8. Pengambilan Data Amplitudo dan Ketebalan Lapisan Air

\section{HASIL DAN PEMBAHASAN}

\subsection{Perubahan Ketebalan Film}

Berdasarkan Gambar 9, maka ketebalan lapisan air mengalami kenaikan seiring dengan kenaikan input ratio kecepatan superfacial air. Prosentase rata-rata kenaikan ketebalan film untuk setiap kenaikan input ratio sebesar 12\% dengan standard deviasi sebesar 5,4\%. Hal menarik apabila perubahan ketebalan lapisan air ditinjau berdasarkan titik pengamatan. Ketebalan lapisan air dengan input ratio yang sama pada titik 10D, 40D dan 100D akan terus mengalami peningkatan, namun ketika di titik 220D ketebalan lapisan air terlihat mengalami penurunan. Fenomena perbedaaan kecenderungan perubahan ketebalan lapisan air antara titik pengamatan ini akan menyebabkan terjadinya perubahan gaya inersia akibat kecepatan relatif antara kedua fasa minyak dan air yang bekerja pada fluida tersebut. 


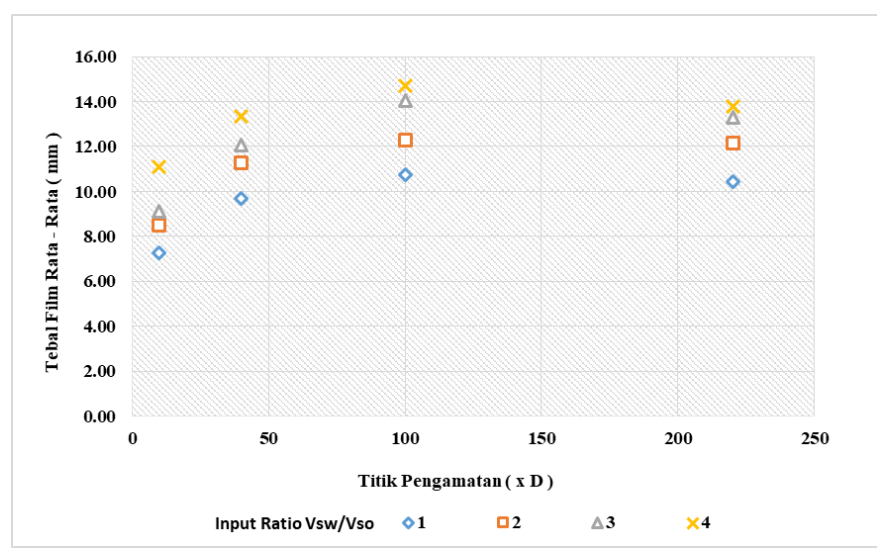

Gambar 9. Ketebalan Rata-Rata Lapisan Air Vso 0,073 m/s Pada Titik Pengamatan 10D, 40D, 100D dan 220D

Besarnya perubahan gaya inersia dapat dilihat pada hasil perhitungan Froude Number dengan mengacu ke persamaan (1) maka diperoleh hasil seperti pada Gambar 10. Pada kondisi gaya gravitasi yang konstan, maka pola tebal lapisan air berkebalikan dengan pola perubahan bilangan Froude. Gaya inersia dipengaruhi oleh kecepatan fasa fluida, dimana kecepatan fasa pada suatu titik (in situ velocity) dipengaruhi oleh hold up fluid (perbandingan luas penampang melintang suatu titik dibagi luas penampang awal).

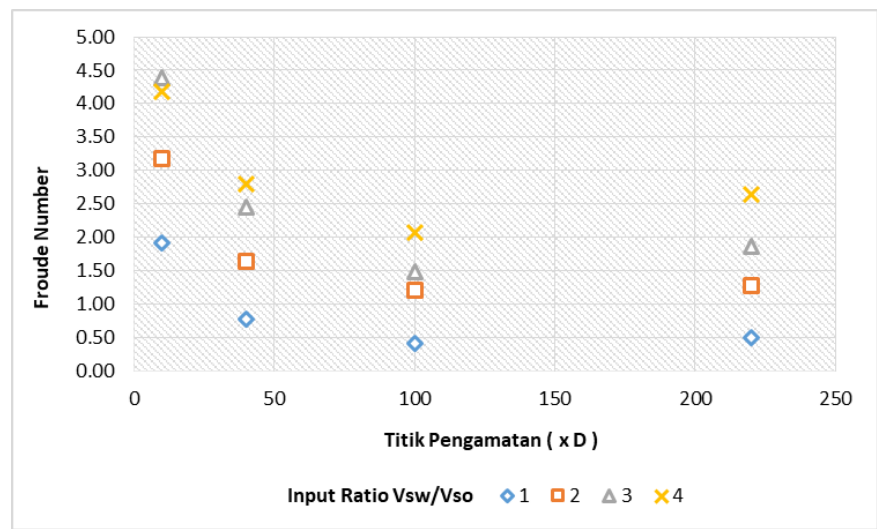

Gambar 10. Froude Number Vso 0,073 m/s Pada Titik Pengamatan 10D, 40D, 100D dan 220D 


\subsection{Kondisi Onset dan Pertumbuhan Gelombang}

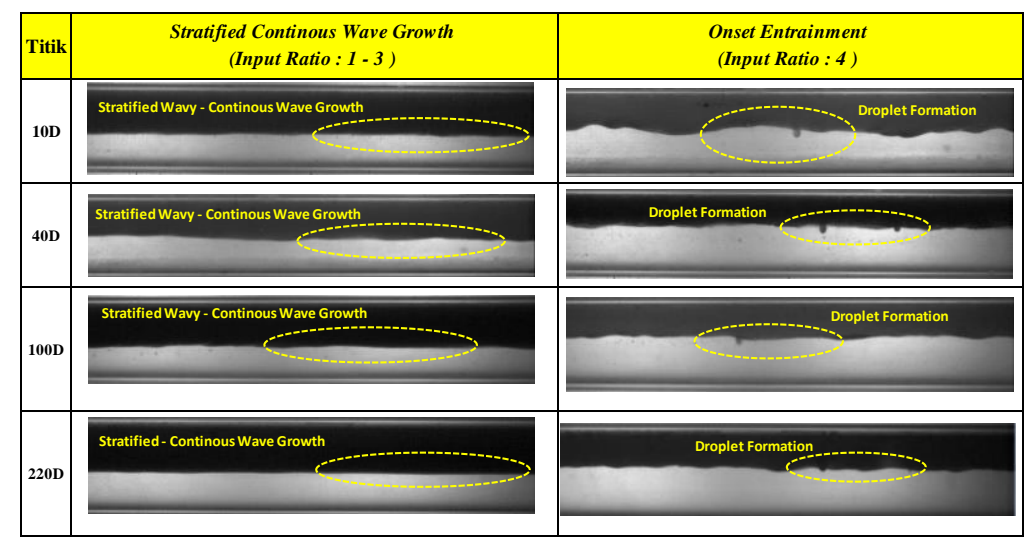

Gambar 11. Visualisasi Pertumbuhan Gelombang Terhadap Input Ratio

Proses pengamatan secara visual pada perubahan ketinggian lapisan air dan pertumbuhan amplitudo gelombang untuk setiap kondisi operasi input ratio dan titik pengamatan dilakukan secara cermat. Hasil observasi secara kualitatif dapat dilihat pada Gambar 11. Pada nilai input ratio kecepatan superfacial 1 sampai dengan 3, terjadi kenaikan amplitudo gelombang tanpa disertai kemunculan droplet disepanjang aliran kontinu. Pada fasa ini maka kita sebut dengan fasa pertumbuhan gelombang. Hal menarik terjadi ketika nilai input ratio 4, dimana amplitudo gelombang mengalami kenaikan dengan disertai munculnya droplet di sepanjang aliran kontinu pada semua titik pengamatan. Droplet merupakan indikator aliran gelombang dalam kondisi tidak stabil. Ketika kondisi gelombang mulai muncul droplet, sering kita sebut dengan kondisi onset.

Hasil pengolahan citra amplitudo gelombang dalam grafik Probability Distribution Function (PDF) untuk setiap input ratio kecepatan superfacial air terhadap minyak pada setiap titik pengamatan dapat dilihat pada Gambar 12 - 15. Pada titik pengamatan 10D dan 40D yang ditunjukkan oleh Gambar 12 dan 13, besarnya amplitudo ketika dalam fasa pertumbuhan gelombang mengalami kenaikan dari rentang $0,72 \mathrm{~mm}$ menjadi $0,72 \mathrm{~mm}-1,44 \mathrm{~mm}$. Pada kondisi onset, maka amplitudo mengalami kenaikan menjadi 1,44 mm - 4,32 mm dengan amplitudo maximum 5,04 mm. Pada titik pengamatan 100D pada Gambar 14, amplitudo gelombang pada fasa pertumbuhan gelombang mengalami kanaikan dari rentang $0,72 \mathrm{~mm}-$ 1,44 mm menjadi 1,44 mm - 2,88 mm. Sedangkan pada kondisi onset, nilai amplitudo relatif konstan pada rentang 1,44-2,88 mm. Pada titik pengamatan 220D pada Gambar 15, besarnya rentang perubahan kenaikan amplitudo relatif sama baik pada fasa pertumbuhan gelombang maupun dalam kondisi onset sebesar 0,72 mm - 1,44 mm.

Secara keseluruhan, kenaikan input ratio kecepatan superfacial air terhadap minyak akan menyebabkan terjadinya kenaikan amplitudo gelombang. Kenaikan input ratio kecepatan superfacial fluida akan menyebabkan terjadinya kenaikan gaya suction pressure sebagai fungsi kecepatan relatif antara kecepatan fasa kontinu dengan kecepatan gelombang. Suction pressure force akan menyebabkan gelombang bergerak ke atas dan ke bawah sehingga menyebabkan kenaikan amplitudo dan gelombang menjadi tidak stabil. Hal ini sesuai dengan hasil penelitian Al-Wahabai dan Angeli (2007) yang dapat dilihat pada Bab I. 


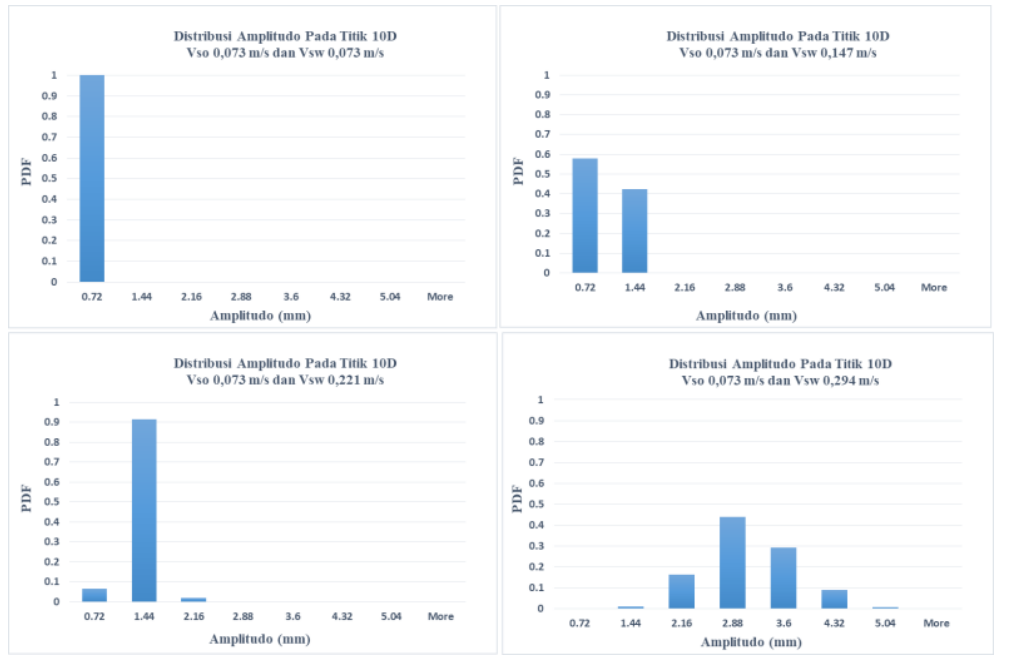

Gambar 12. Probability Distribution Function (PDF) Amplitudo Pada Titik 10D
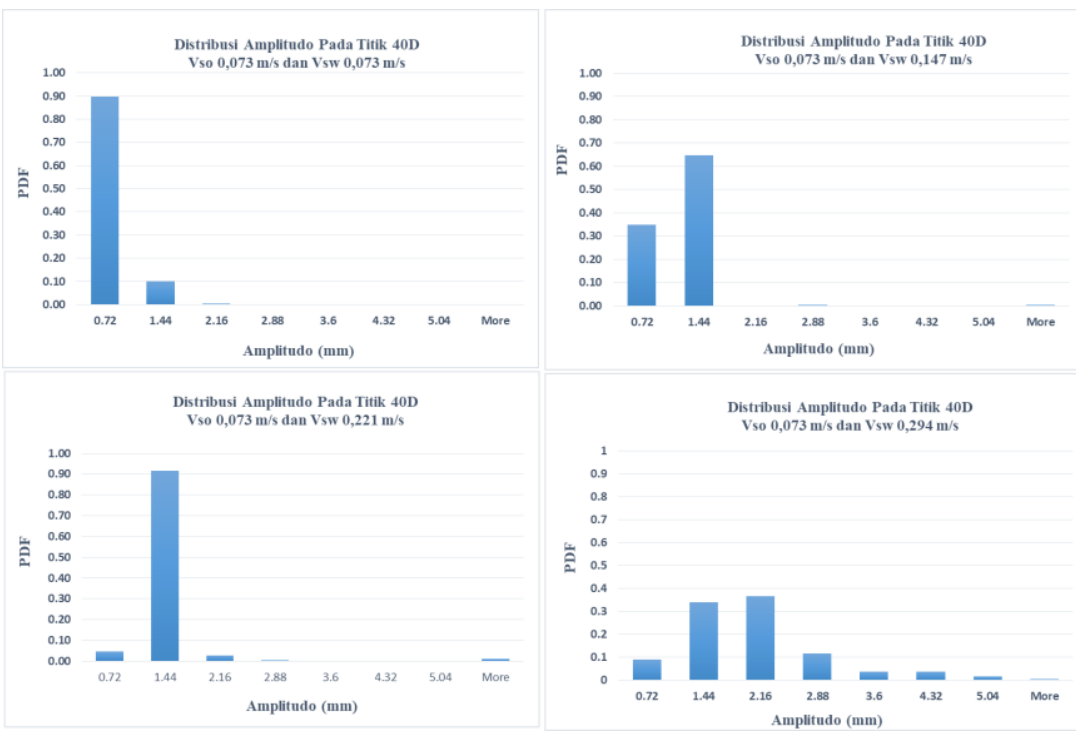

Gambar 13. Probability Distribution Function (PDF) Amplitudo Pada Titik 40D 


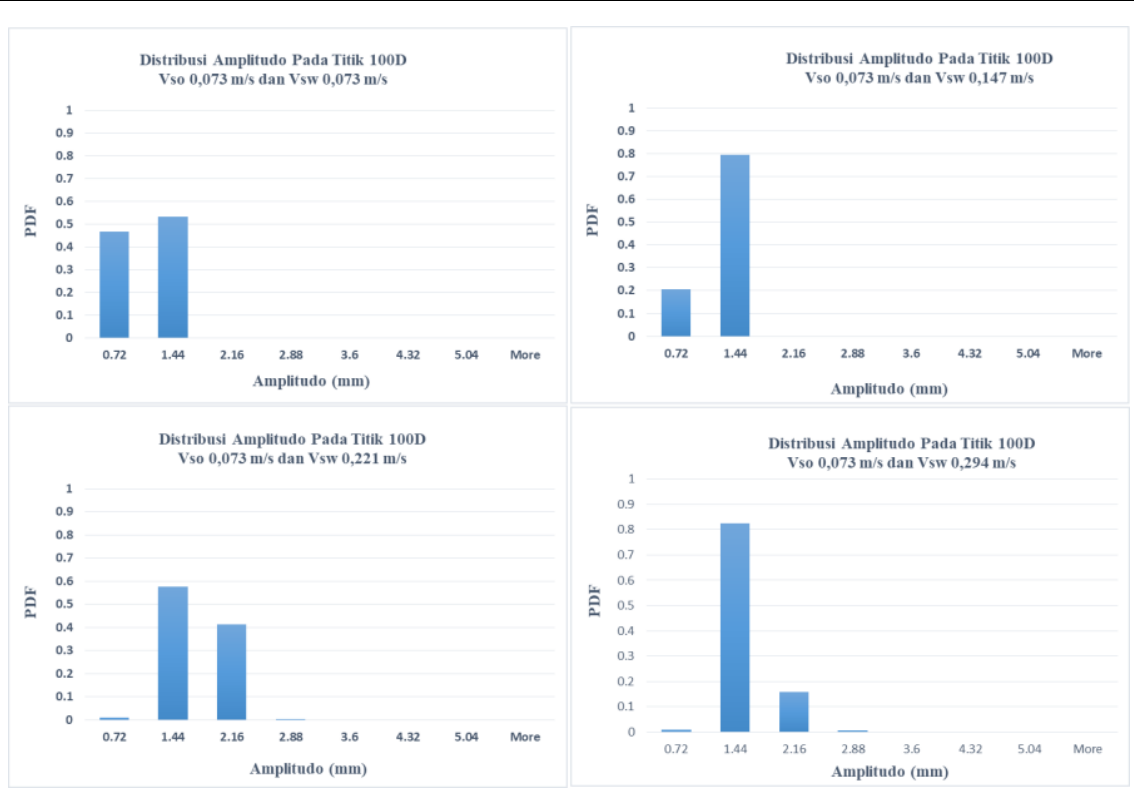

Gambar 14. Probability Distribution Function (PDF) Amplitudo Pada Titik 100D

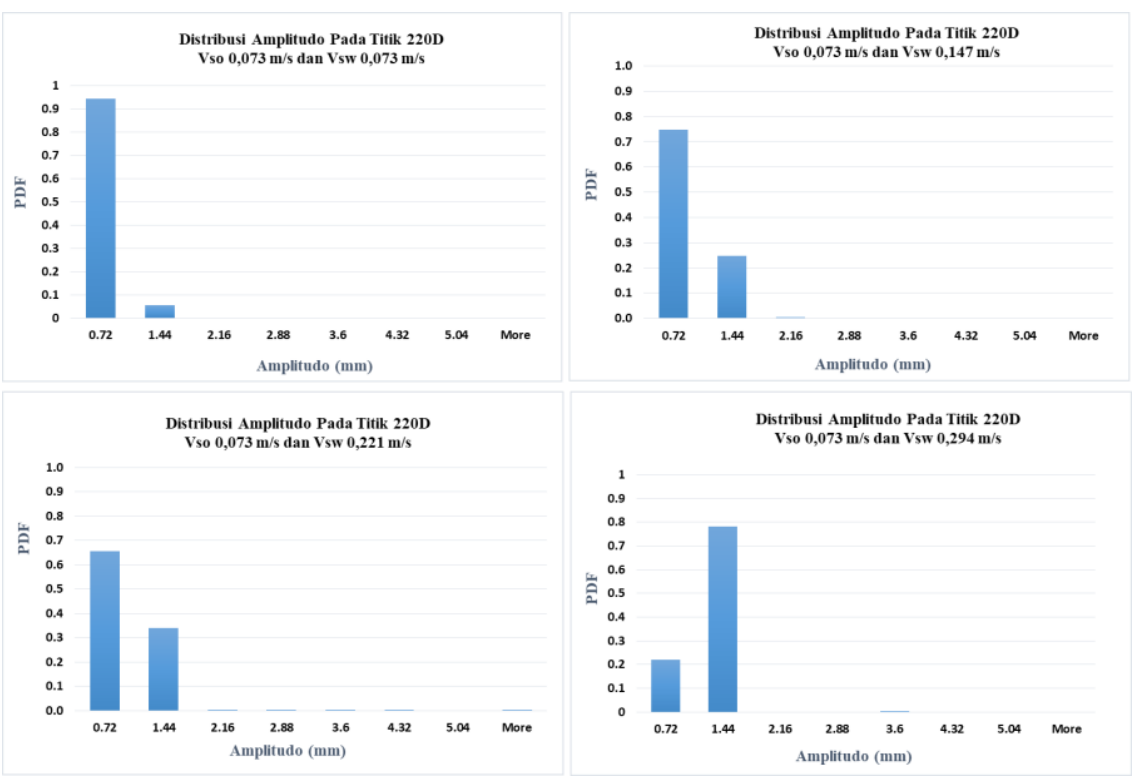

Gambar 15. Probability Distribution Function (PDF) Amplitudo Pada Titik 220D

Pengaruh kenaikan input ratio kecepatan superfacial air terhadap minyak akan cenderung mengalami penurunan pada titik menjauhi inlet sumber aliran. Kondisi perubahan pola kenaikan amplitudo terhadap inlet ini sangat dipengaruhi oleh gaya viskositas interfacial aliran. Besarnya gaya viskositas interfacial aliran dapat lihat dengan bilangan Reynolds. Pada titik yang menjauhi inlet sumber aliran maka nilai interfacial Reynolds Number akan cenderung mengalami penurunan. Grafik interfacial Reynolds Number dapat dilihat pada Gambar 16. 


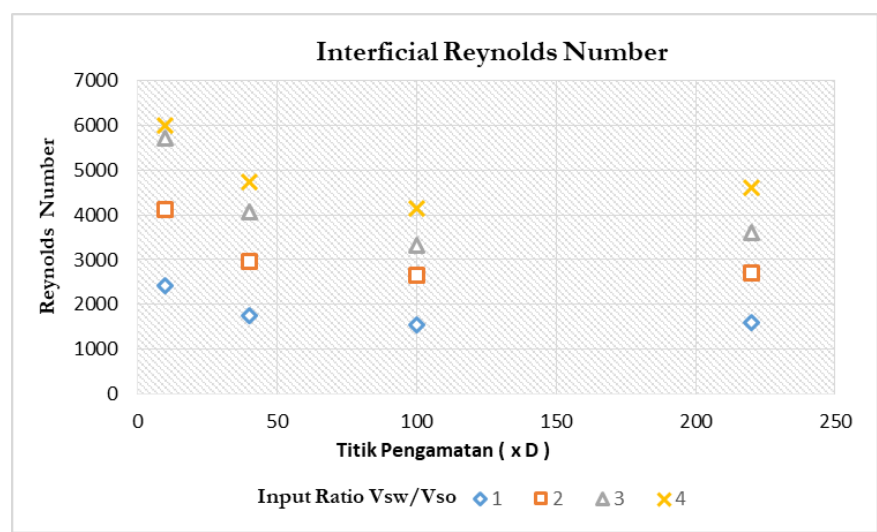

Gambar 16. Interfacial Reynolds Number Vso 0,073 m/s Pada Titik Pengamatan 10D, 40D, 100D dan $220 \mathrm{D}$

\subsection{Perbandingan Amplitudo Rata-Rata Terhadap Penelitian Lain}

Besarnya amplitudo rata-rata dalam penelitian ini diperoleh dengan mengambil nilai rata-rata dari 5543 sample nilai amplitudo pada setiap input ratio kecepatan superfacial air terhadap minyak dalam satu titik pengamatan. Standard deviasi hasil rata-rata amplitudo berkisar 7,4 \% sampai dengan 19,8 \% dan error rata-rata 2,8 \%. Seperti yang terlihat pada Gambar 17, untuk rezim aliran stratified wavy, kenaikan amplitudo terjadi seiring dengan kenaikan input ratio kecepatan superfacial air-minyak. Pada rentang input ratio 1 - 4, maka selisih kenaikan amplitdo tertinggi sebesar 2,2 mm pada titik $10 \mathrm{D}$ atau 0,24 meter dari inlet aliran dan kenaikan amplitudo terendah sebesar $0,4 \mathrm{~mm}$ pada titik $220 \mathrm{D}$ atau 5,28 meter dari inlet aliran.

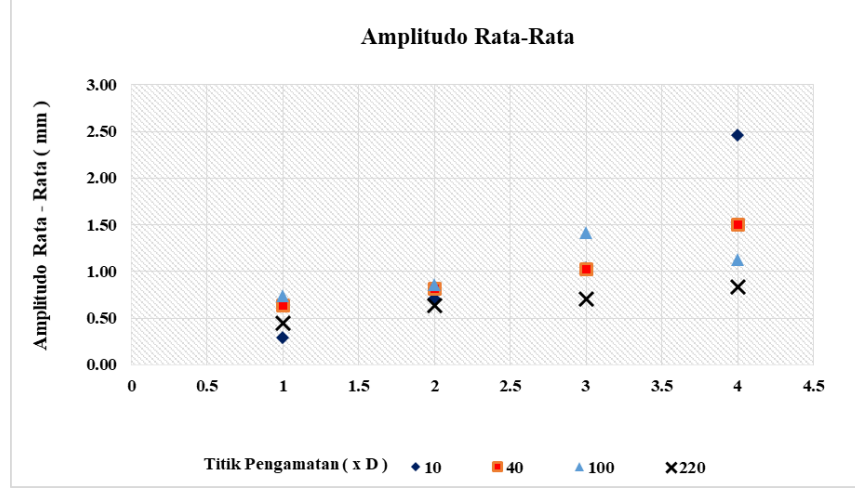

Gambar 17. Amplitudo Rata-Rata Vso 0,073 m/s Pada Titik Pengamatan 10D, 40D, 100D dan 220D

(Penelitian)

Al-Wahabai dan Angeli (2011) melakukan penelitian karakteristik amplitudo pada aliran dua fasa air-minyak yang dilirkan pada pipa stainless steel dengan diameter $38 \mathrm{~mm}$ dengan 12 variasi input ratio kecepatan superfacial air terhadap minyak di titik pengamatan 6 meter dari inlet aliran. Minyak yang digunakan memiliki properties massa jenis $828 \mathrm{~kg} / \mathrm{m}^{3}$ dan viskositas 5,5 $\mathrm{mPa} \cdot \mathrm{s}$. Pengambilan data amplitudo dilakukan dengan wire probe yang dapat mendeteksi ketinggian lapisan air dan minya berdasarkan perbedaan nilai konduktansi nya. Hasil pengukuran amplitudo rata - rata untuk input ratio kecepatan superfacial air terhadap minyak dari 0,2 - 11 
diperoleh nilai amplitudo terendah $0,8 \mathrm{~mm}$ dan tertinggi $2 \mathrm{~mm}$ atau mengalami kenaikan amplitudo sebesar 1,2 mm dengan persebaran seperti terlihat pada Gambar 18 dan error rata rata sebear $2,3 \%$.

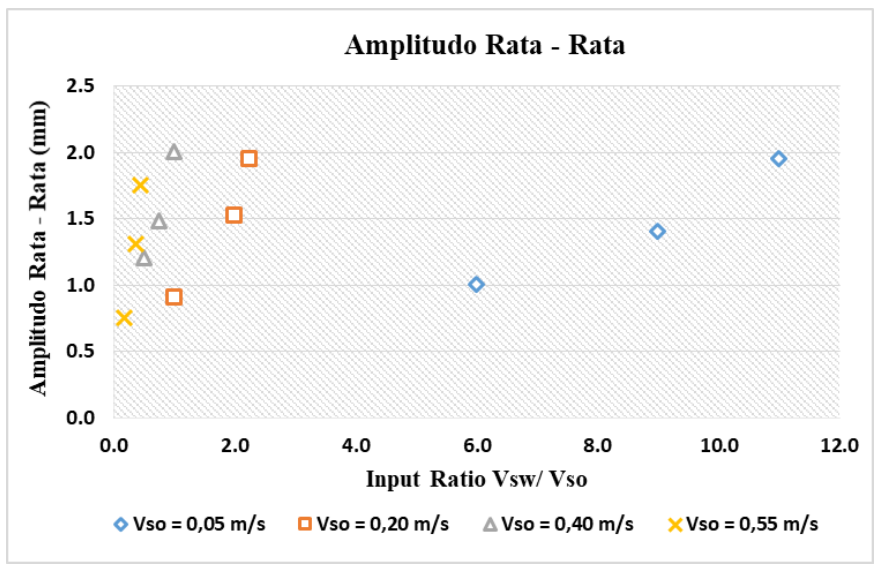

Gambar 18. Amplitudo Rata-Rata Variasi Input Ratio Pada Titik Pengamatan 6 Meter Dari Inlet (Al-

Wahabai dan Angeli, 2011)

Berdasarkan grafik pada Gambar 17 dan Gambar 18, maka dapat terlihat kesesuaian bahwa pada kecepatan superfacial minyak yang dijaga konstan maka untuk setiap kenaikan input ratio kecepatan superfacial air terhadap minyak akan menyebabkan kenaikan amplitudo gelombang antarmuka. Besarnya kenaikan amplitudo pada rezim stratified wavy akan berhenti pada nilai tertentu sebelum terjadi proses transisi ke rezim non stratified.

\section{KESIMPULAN}

Kenaikan input ratio kecepatan superfacial air terhadap minyak $\left(\mathrm{v}_{\mathrm{sw}} / \mathrm{v}_{\mathrm{so}}\right)$ pada aliran dua fasa air - minyak dalam rezim aliran stratified wavy akan menyebabkan terjadinya kenaikan amplitudo antarmuka gelombang dan ketinggian rata-rata lapisan air. Perubahan amplitudo dipengaruhi oleh perubahan gaya suction pressure yang bekerja pada antarmuka gelombang. Pada titik yang semakin menjauhi inlet aliran maka rentang kenaikan amplitudo untuk setiap kenaikan input ratio kecepatan superfacial akan semakin kecil dibandingkan pada titik yang dekat dengan inlet aliran. Perubahan range kenaikan amplitudo ini dipengaruhi oleh gaya viskositas fluida yang bekerja pada antarmuka fasa.

\section{DAFTAR PUSTAKA}

Al-Sarkhi, A., Pereyra, E., Mantilla, I., Avila, 2017, Dimensionless oil-water stratified to non-stratified flow pattern transition, Journal of Petroleum Science and Engineering, 151, 281-291.

Al-Wahabai,T., Angeli, Panagiota, 2011, Experimental study on interficial waves in stratified horizontal oil-water flow, International Journal of Multiphase Flow, 37, 930-940.

Al-Wahaibi, Talal, Angeli, Panagiota, 2007, Transition Between Stratified and Non Stratified Horizontal Oil Water Flows Part I: Stability Analysis, Chemical Engineering Science, 62, 2915-2928.

Angeli, P., Hewitt, G.F., 2000, Flow structure in horizontal oil water Flow, International Journal of Multiphase Flow 26, 1117-1140. 
A.I. Santosa dan A. Widyaparaga. / Journal of Mechanical Design and Testing 2(2), (2020), 111-123

De Castro, Marcelo S., Pereira, Cleber C., Dos Santos, Jorge N., Rodriguez, Oscar M.H., 2011, Geometrical and kinematic properties of interfacial waves in stratified oil-water fliw in inclined pipe, Journal Experimental and Fluid Science 37 (2012) 171-178.

Kuntoro, Hadiyan Yusuf, Hudaya, Akhmad Zidni, Dinaryanto, Okto, Majid , Akmal Irfan, Deendarlianto. 2016, An improved algorithm of image processing technique for film thickness measurement in a horizontal stratified gas-liquid two-phase flow. AIP Conference Proceedings 1737, 040010. 